\title{
Hestekastanje - naturlegemiddel mot venøs insuffisiens
}

\author{
Hestekastanje er et populært naturprodukt i hele Europa. I folkemedi- \\ sinen har det vært brukt som et antiinflammatorisk middel mot en \\ rekke tilstander. I Norge brukes hestekastanje hovedsakelig mot \\ kronisk venøs insuffisiens. Forskningen er ufullstendig, men antyder \\ at midlet har effekt mot kronisk venøs insuffisiens på kort sikt.
}

Se også kunnskapsprøve på www.tidsskriftet.no/quiz
Hestekastanjen (Aesculus hippocastanum) er en tresort i såpebærfamilien med tykk og relativt kort stamme og stor, rund krone (1). Treet kan bli 25-30 m høyt, og har store blader inndelt i 5-7 deler med fintaggede kanter. Det stammer opprinnelig fra Nord- og Sentral-Asia, men har nå spredt seg til resten av verden. I Norge vokser det i store deler av lavlandet, så langt nord som Nordland fylke. Hestekastanjen kan bli 200-400 år gammel. ca. $4 \mathrm{~cm}$ i diameter, og ved modning åpner de seg og åpenbarer en eller flere store, glatte, brune nøtter eller frø. Disse er svært giftige og kan forårsake alvorlige gastrointestinale og nevrotoksiske reaksjoner hvis de spises. Frøene kan forveksles med de spiselige frøene fra kastanjetreet (Castanea sativa), som tilhører bøkefamilien.

\section{Materiale og metode}

Denne artikkelen bygger på et ikke-systematisk litteratursøk i databasene Cochrane, Treets frukter er grønne, taggete og runde,
Natural Medicines Comprehensive Database, Micromedex, MedicinesComplete og Medline, med et skjønnsmessig utvalg av artikler basert på forfatternes erfaring innen feltet.

\section{Tradisjonell bruk}

Folkemedisinen har benyttet ekstrakter fra hestekastanjens frø, bark og blader (2). Ekstrakter fra frø er blitt brukt mot åreknuter, hemoroider, tromboflebitter, diaré, feber og prostatahyperplasi, mens barken er blitt brukt mot malaria og dysenteri. Bark har også vært brukt i omslag mot lupus og overflatiske sår. Treets blader har vært brukt for å behandle eksem, menstruasjonssmerter, bløtdelshevelser, hoste, artritt og andre revmatiske lidelser. I Norge brukes hestekastanje hovedsakelig mot tilstander forårsaket av venøs insuffisiens. I enkelte andre land, bl.a. i Asia, brukes hestekastanje intravenøst som et antiinflammatorisk middel etter traume eller kirurgi $(3,4)$.
Tabell 1 Effekt av hestekastanje på symptomer og tegn ved kronisk venøs insuffisiens ifølge Cochrane-oversikt (7)

\begin{tabular}{|c|c|c|c|c|}
\hline Parameter & $\begin{array}{l}\text { Antall studier } \\
\text { på hestekastanje- } \\
\text { ekstrakt vs. } \\
\text { placebo }\end{array}$ & $\begin{array}{l}\text { Antall studier } \\
\text { med signifikant } \\
\text { Reduksjon } \\
(p<0,05)\end{array}$ & $\begin{array}{l}\text { Antall inkluderte } \\
\text { studier egnet for } \\
\text { metaanalyse }\end{array}$ & $\begin{array}{l}\text { Gjennomsnittlig } \\
\text { reduksjon vs. placebo } \\
\text { ved metaanalyse } \\
(95 \% \mathrm{KI})\end{array}$ \\
\hline Volum & 7 & Ikke oppgitt & 6 & $\begin{array}{c}32,1 \mathrm{ml}^{1} \\
(13,5-50,7)\end{array}$ \\
\hline Omkrets, ankel & 7 & 5 & 3 & $\begin{array}{l}4,7 \mathrm{~mm}^{1} \\
(1,1-8,3)\end{array}$ \\
\hline Omkrets, legg & 7 & 3 & 3 & $\begin{array}{l}3,5 \mathrm{~mm}^{1,2} \\
(0,6-6,5)\end{array}$ \\
\hline Smerte & 7 & 6 & 1 & $\begin{array}{l}42,4 \mathrm{~mm}^{1,3} \\
(34,9-49,9)\end{array}$ \\
\hline$\emptyset$ dem & 6 & 4 & 1 & $\begin{array}{l}40,1 \mathrm{~mm}^{1,3} \\
(31,6-48,6)\end{array}$ \\
\hline Kløe & 8 & 4 & 0 & Ikke aktuelt \\
\hline \multicolumn{5}{|c|}{$\begin{array}{l}1 \text { Vekting basert på effekten dividert med verdien av variansen (weighted mean difference, WMD) } \\
{ }^{2} \text { Data utregnet med samlet (poolet) analyse } \\
{ }^{3} \text { Reduksjon i mm på } 100 \mathrm{~mm} \text { visuell analog skala }\end{array}$} \\
\hline
\end{tabular}

\section{Farmakologiske effekter}

Uforedlet hestekastanjefrø inneholder toksinet esculin. Dette hydrolyseres til et hydroksykumarin og er dermed beslektet med bl.a. warfarin. Esculin kan gi økt blødningsfare (1). Hestekastanjefrø blir på grunn av denne komponenten videreforedlet, noe som gir et standardisert ekstrakt, som i innholdsfortegnelsen for denne typen preparater forkortes HCSE (horse chestnut seed extract). Det farmakologisk aktive stoffet i dette ekstraktet kalles escin, og ekstraktet er hovedbestanddel i naturlegemidlet Venastat, som i Norge selges under indikasjonen hevelse og uro i beina (5). En daglig dose på $600 \mathrm{mg}$ ekstrakt vil inneholde 100-150 mg escin (1).

Ved kronisk venøs insuffisiens er det sett en akkumulering av leukocytter i affiserte ekstremiteter (6). Når disse aktiveres, frisettes en rekke substanser, deriblant frie radikaler og enkelte enzymer. Disse enzymene er involvert i nedbrytningen av proteoglykaner, som regulerer kapillær rigiditet og porestørrelse. Virkningsmekanismen til escin er ikke fullstendig klarlagt, men det antas at effekten på kronisk venøs insuffisiens kan skyldes at leukocyttaktiveringen hemmes (1, 3 ). Dermed reduseres transkapillær filtrasjon av vann og protein. I tillegg er escin forbundet med økt syntese av prostaglandinet PGF $_{2 \mathrm{a}}$, som gir venøs konstriksjon (3). Det er i hovedsak escin som har vært gjenstand for studier, men hestekastanjeekstrakt inneholder også andre farmakologisk aktive komponenter, bl.a. flavonoider, som er allment kjent for å ha antiinflammatorisk effekt (3).

\section{Effekt}

En Cochrane-artikkel fra januar 2006 gir en oversikt over effekt og sikkerhet ved bruk av hestekastanjeekstrakt tatt peroralt i behandling av kronisk venøs insuffisiens (7). I denne studien er det inkludert 17 studier utført i perioden 1976-2002. Forfatterne konkluderte med at ekstraktet sannsynligvis var assosiert med en reduksjon i ankel- og leggomkrets og ga bedring av subjektive symptomer ved kronisk venøs insuffisiens som leggsmerte, kløe og følelse av utmattelse og anspenthet. Effekten funnet i de inkluderte studiene er oppsummert i tabell 1. Studiene er av varierende og til dels usikker kvalitet. Enkelte av studiene har som formål å finne riktig dosering av andre preparater og er dermed dårligere egnet til å vise effekt av escin. Andre studier mangler gode beskrivelser av hvordan symptom- og funnskår er laget, 


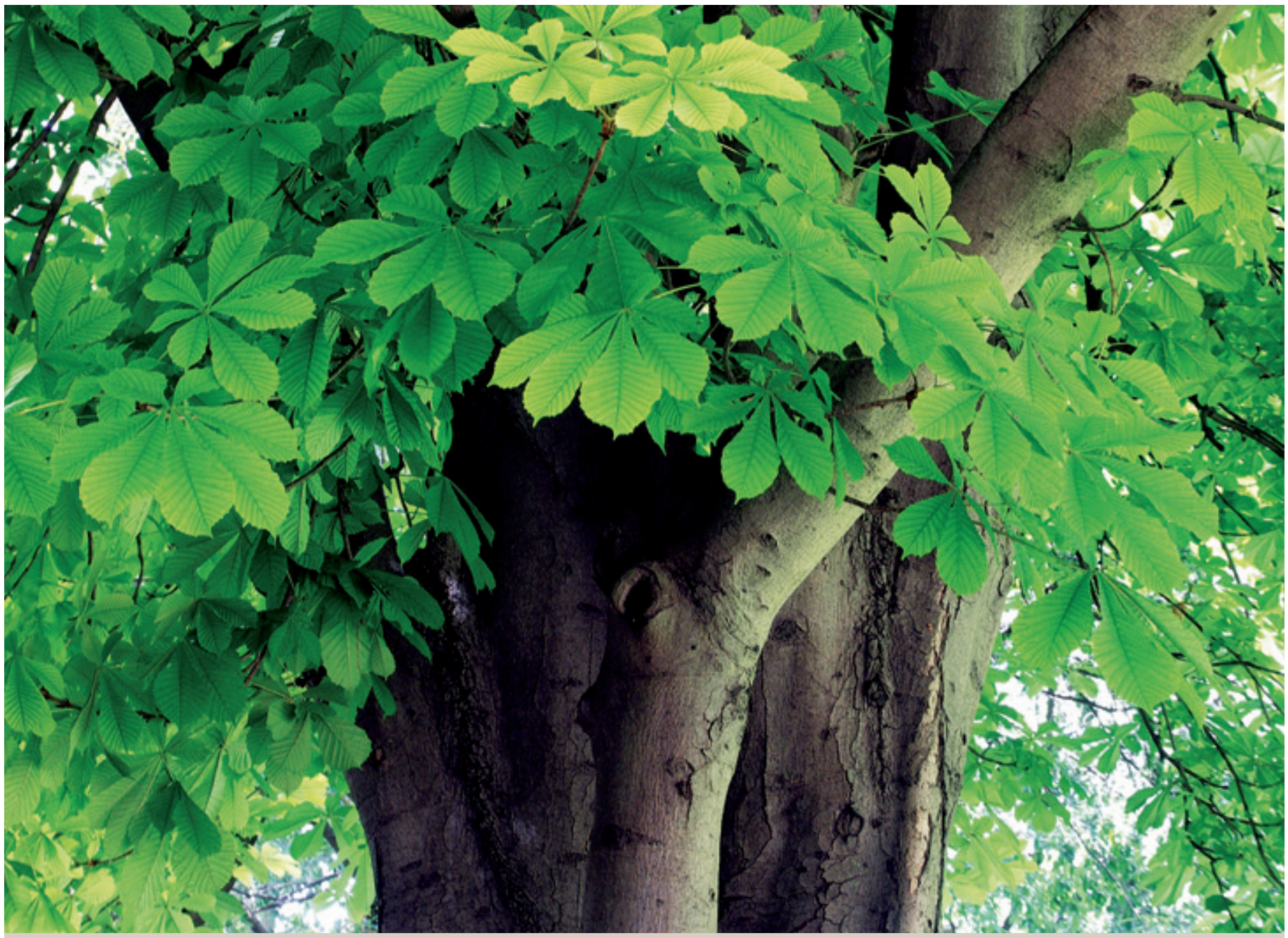

Hovedbudskap Ekstrakt fra hestekastanje kan være et alternativ til kompresjonsbehandling ved lav til moderat grad av kronisk venøs insuffisiens. Det foreligger kun dokumentasjon for korttidsbehandling. Få alvorlige bivirkninger er rapportert. Det foreligger begrenset kunnskap om interaksjoner med andre legemidler.

Foto Joaquim Alves Gaspar (c) Br

eller de baserer seg på subjektive vurderinger fra pasientene. I enkelte av overkrysningsstudiene var det ikke lagt inn medikamentfrie perioder, og muligheten for overføringseffekt kan dermed ikke utelukkes. Flere av studiene har svært vide inklusjonskriterier og få deltakere, noen har manglende eller dårlig blinding. Studiene som ble inkludert, ble gitt en skår for i hvor stor grad pasientens plassering i de ulike behandlingsgruppene var skjult. Kun tre studier fikk høyeste skår, de øvrige fikk nest høyeste. Videre hadde kun et fåtall av studiene data som tydet på at etterlevelse ble monitorert. Felles for alle studiene er at de foregår over kort tid og ikke omtaler langtidseffekter av behandling med escin.

Den kliniske relevansen av den reduksjonen som er funnet $i$ volum og omkrets av underekstremitet ved bruk av hestekastanjeekstrakt, er usikker. I studiene har man ikke sett på midlets virkning på langtidseffekter av kronisk venøs insuffisiens, som for eksempel utvikling av sår. Alt $i$ alt ser det ut til at hestekastanjeekstrakt utgjør en effektiv behandling av kronisk venøs insuffisiens på kort sikt. Det kreves imidlertid ytterligere randomiserte, kontrollerte studier med en mer nøyaktig design før man kan trekke konklusjoner om langtidsbruk (7). I andre systematiske oversikter som omhandler effekt og sikkerhet ved bruk av hestekastanjeekstrakt mot kronisk venøs insuffisiens, konkluderer man med at det ser ut til å være en effektiv og trygg behandling av denne tilstanden $(8,9)$.

\section{Bivirkninger og interaksjoner}

Hestekastanjeekstrakt har vært i bruk i Tyskland i flere tiår, der det er det tredje mest solgte naturmiddel. Få bivirkninger er rapportert, og preparatet regnes for å være godt tolerert. Unntak er enkelttilfeller av kløe, hodepine, svimmelhet, leggkramper, kvalme og magesmerter (5). Det har også vært rapportert to tilfeller av toksisk nefropati som trolig har kommet som følge av inntak av svært høye doser escin. Andre studier har imidlertid vist at escins nefrotoksiske potensial kun er relevant når nyrene allerede er skadet og/eller i situasjoner der escin er fortrengt fra binding til plasmaproteiner (3).

Dyrestudier har vist at hestekastanjeekstrakt kan senke blodsukkeret (10). Man anbefaler derfor forsiktighet ved samtidig bruk av andre blodsukkersenkende preparater og at blodsukkeret monitoreres hos disse pasientene under behandlingen.

Hestekastanje kan teoretisk øke blødningsfaren og bør derfor brukes med forsiktighet hos pasienter som enten har en blødningssykdom eller bruker legemidler som øker blødningsfaren (10).

Escin kan muligens potensere effekten av antikoagulantia, som warfarin (5). Denne interaksjonen er ikke klinisk dokumentert, kun empirisk beskrevet, men det anbefales at man unngår bruk av hestekastanje hos pasienter som bruker denne typen legemidler (10). Escin binder seg også til plasmaproteiner og kan derfor teoretisk påvirke bindingen av andre legemidler, men heller ikke dette er hittil sett hos mennesker $(5,10)$. En nylig publisert studie antyder at hesteka- 


\section{Ramme}

\section{Dokumentasjonskrav til naturlegemidler}

Det må kunne dokumenteres at naturlegemidlets innholdsstoffer har vært i tradisjonell bruk i Europa eller Nord-Amerika i minst 30 år, har anerkjent effekt og er tilstrekkelig sikre. Krav til godkjenning av naturlegemiddels kvalitet er like strenge som for vanlige legemidler (Statens legemiddelverk)

stanje kan ha en generelt hemmende effekt på legemiddelmetaboliserende enzymer (11). For øvrig er det lite kunnskap om interaksjoner med andre legemidler.

\section{Oppsummering}

Hestekastanjeekstrakt, solgt i Norge som naturlegemiddel under navnet Venastat, har i flere systematiske oversikter og metaanalyser vist seg å være mer effektiv korttidsbehandling av kronisk venøs insuffisiens enn placebo. Det er hittil rapportert få og lite alvorlige bivirkninger. Forsiktighet ved samtidig bruk av antikoagulantia og blodsukkersenkende preparater anbefales.

Virkningsmekanismene er ikke avklart, men er antatt å være forbundet med nedsatt frisetting av enzymer involvert i regulering av den kapillære permeabilitet og også med økt venetonus forbundet med økt syntese av $\mathrm{PGF}_{2 \mathrm{a}}$. En måneds behandling med preparatet koster i Norge kr 220-240. Eksisterende dokumentasjon foreslår hestekastanje som et alternativ til kompresjonsbehandling ved korttidsbehandling hos pasienter med lav til moderat grad av kronisk venøs insuffisiens. Det er imidlertid et klart behov for flere kliniske studier for å bekrefte dette og å avgjøre om det også kan ha langtidseffekter på tilstanden.

\section{Camilla Borthen Methlie}

camilla.borthen@helse-bergen.no Jan Schjøtt

Laboratorium for klinisk biokjemi

Seksjon for klinisk farmakologi

Haukeland universitetssykehus

5021 Bergen

\section{Oppgitte interessekonflikter: Ingen}

\section{Litteratur}

1. New Zealand Ministry of Health. An evidencebased resource about complementary and alternative medicine. wwW.cam.org.nz (12.8.2008).
2. Natural Medicines Comprehensive Database. www.naturaldatabase.com (12.8.2008)

3. Barnes J, Anderson LA, Philipson JD. Herbal medicines. www. medicinescomplete.com (12.8.2008)

4. Sweetman S, red. Escin. Martindale: The Complete Drug Reference. London: Pharmaceutical Press, 2008. www.thomsonhc.com (12.8.2008).

5. Statens legemiddelverk. Preparatomtale (SPC) Venastat. www legemiddelverket no/preparatomtaler (12.8.2008).

6. Niren A, Bergan JJ. Chronic venous ulcer. BMJ 1997; 314: 1019-23.

7. Pittler MH. Ernst E. Horse chestnut seed extract for chronic venous insufficiency. Cochrane Database Syst Rev 2006; nr. 1: CD003230.

8. Ottillinger B, Greeske K. Rational therapy of chronic venous insufficiency - chances and limits of the therapeutic use of horse-chestnut seeds extract. BMC Cardiovasc Disord 2001; 1: 5.

9. Suter A, Bommer S, Rechner J. Treatment of patients with venous insufficiency with fresh plant horse chestnut extract: A review of 5 clinical studies. Adv Ther 2006; 23: 179-90.

10. The U.S. National Library of Medicine, The National Institute of Health. Medline Plus: Horse Chestnut. www.medlineplus.gov (6.8.2008).

11. Hellum B, Hu Z, Nilsen OG. The induction of CYP1A2, CYP2D6 and CYP3A4 by six trade herbal products in cultured primary human hepatocytes. Basic Clin Pharmacol Toxicol 2007; 100: 23-30.

Manuskriptet ble mottatt 17.3. 2008 og godkjent 18. 12. 2008. Medisinsk redaktør Anne Kveim Lie. 